\title{
POKRAJINSKOEKOLOŠKA ČLENITEV ZGORNJE GORENJSKE
}

\author{
Andreja Ferreira \\ Gozdarski inštitut Slovenije, Večna pot 2, SI - 1000 Ljubljana, Slovenija \\ e-mail: andreja.ferreira@gozdis.si
}

Izvirni znanstveni članek

COBISS 1.01

\section{Izvleček}

Pokrajinskoekološki metodološki pristop je zaradi holistične obravnave najprimernejši za proučevanje odnosov med posameznimi pokrajinskoekološkimi enotami ter njihovimi vplivi na rabo tal in človekove dejavnosti. Zgornjo Gorenjsko smo razčlenili na 5 pokrajinskoekoloških tipov in 19 pokrajinskoekoloških enot. Pokrajinskoekološki tipi in pokrajinskoekološke enote so pokazali veliko notranjo diferenciacijo območja, ki v primeru obstoječih teritorialnih enot, kot so katastrske občine, občine itd., ne pridejo do izraza. Homogenost pokrajinskoekoloških tipov in pokrajinskoekoloških enot omogoča preprostejšo interpretacijo podatkov in boljše rezultate.

Ključne besede: pokrajinska ekologija, pokrajinskoekološka členitev, Zgornja Gorenjska.

\section{LANDSCAPE-ECOLOGICAL DIVISION OF THE UPPER GORENJSKA REGION}

\begin{abstract}
The landscape-ecological methodological approach is due to its holistic approach most suitable for the study of relations between separate landscape-ecological units and their impacts on land-use and human activities. The Upper Gorenjska region was divided into 5 landscape-ecological types and 19 landscape-ecological units. Landscape-ecological types and landscape-ecological units showed a high inner differentiation of the studied area, which is not clearly detected in the existing territorial units, such as cadastral districts, councils, etc. The homogeneity of landscape-ecological types and landscape-ecological units enabled a simpler interpretation of the obtained data and, in turn, better results.
\end{abstract}

Key words: landscape ecology, landscape-ecological division, Upper Gorenjska. 


\section{UVOD}

Za udejanjanje trajnostnega razvoja so pomembni ustrezna prostorska struktura ter razvoj in sistem planiranja (Praper, 1997). Plut (1999) kot predpogoj za okoljsko, gospodarsko, kulturno in socialno uravnotežen napredek oziroma skladnejši regionalni razvoj izpostavlja sonaravno zasnovane prostorske enote. Na gorskem območju je potreba po členitvi prostora kot osnovi za usmerjanje njegovega razvoja še toliko večja, saj zanj veljajo posebne ekosistemske in socialne razmere, kar pomeni, da preprost prenos državnih ali celo mednarodnih ciljev na to območje ni vedno mogoč (Cilji kakovosti ... 2000).

Za proučevanje odnosov med posameznimi pokrajinotvornimi prvinami in njihovimi vplivi na pokrajinsko rabo ter človekove dejavnosti so se kot najprimernejše izkazale pokrajinskoekološke metode. Zanje je značilno, da dajejo poudarek celostnemu vrednotenju pokrajinskoekoloških elementov ter njihovim medsebojnim zvezam oziroma pokrajinskoekološki strukturi z vidika pogojev za življenje ali za pokrajinsko rabo (Leser, 1976; Gams, 1986). Veda je sicer manj analitična, a se prav zaradi upoštevanja zelo širokega spektra dejavnikov in njihovih medsebojnih odnosov zelo približa realnosti v vsej svoji kompleksnosti. Kljub temu pa pokrajinska ekologija nima enotne, vnaprej predpisane metode, ki bi se jo dalo preprosto uporabiti za različne aplikativne namene. Vsaka naloga oziroma vsako področje raziskave zahteva prilagoditev metode (Wollesen, 1997), prav tako pa se mora metoda prilagoditi natančnosti podatkov oziroma prostorski ravni, na kateri poteka raziskava.

Osnovo v pokrajinski ekologiji predstavlja pokrajinska enota, kije ekološko homogeni del pokrajine v določenem merilu (Zonneveld, 1989). Pri tem je ključnega pomena, da se ugotovi, kateri dejavniki so v pokrajini dominantni (nosilni, razločevalni, determinantni, diferencijski, najbolj jasni, kartografski ...), torej tisti, ki odločilno vplivajo na druge pokrajinske dejavnike ter dejavnosti in imajo hkrati kartografsko uporabnost. Zato je pokrajinskoekološka členitev pokrajine na manjše, bolj ali manj homogene pokrajinskoekološke enote najpomembnejši in najzahtevnejši del pokrajinskoekološkega raziskovanja (Gams, 1998; Natek v Špes in sod. 2002)

V našem primeru smo pokrajinskoekološko členitev izdelali kot podlago za analizo trajnosti dosedanjega razvoja Zgornje Gorenjske, obstoječih gozdnih funkcij (na osnovi karte gozdnih funkcij) ter za usmeritve bodočega razvoja s poudarkom na vlogah gozda. Posebno težo pri njeni izvedbi smo namenili gozdu oziroma dejavnikom, ki odločilno vplivajo na njegovo razporeditev in funkcije. Območje proučevanja je bila, kot rečeno, Zgornja Gorenjska, ki združuje štiri občine: Bohinj, Bled, Jesenice in Kranjsko Goro.

\section{IZVEDBA POKRAJINSKO-EKOLOŠKE ČLENITVE}

Pokrajinskoekološko členitev smo izvedli s pomočjo geografskega informacijskega sistema. Pri tem smo poskušali pridobiti čim novejše in natančnejše podatke, žal pa so nekateri podatki že precej zastareli in v relativno grobih merilih, npr. Karta gozdnih združb je iz leta 1970 in v merilu $1: 100.000$. Ker boljših podatkov ni, smo bili primorani uporabiti tiste, ki so dosegljivi. Enote smo poskušali oblikovati čim bolj objektivno s predhodno postavitvijo 
jasnih meril, na osnovi katerih smo izdelali karte posameznih dejavnikov. $\mathrm{Na}$ osnovi primerjave dobljenih rezulatov smo določili dominantne pokrajinskoekološke dejavnike, ki so imeli poglavitno težo in so v največji meri določili potek meje med posameznimi enotami. Potek detaljne meje smo izrisali na TTN $1: 25.000$ in je bil kot tak subjektiven, prednost tega postopka pa je možnost prilagajanja meje drobnejši geomorfološki izoblikovanosti območja.

Postopek pokrajinskoekološke členitve:

1. klasifikacija in analiza pokrajinskoekoloških dejavnikov,

2. izbor dominantnih pokrajinskoekoloških dejavnikov,

3. določitev končnih mejnih vrednosti dominantnih pokrajinskoekoloških dejavnikov,

4. izdelava kart dominantnih pokrajinskoekoloških dejavnikov,

5. izris pokrajinskoekoloških enot,

6. končen izris meja pokrajinskoekoloških enot na topografski karti.

\section{I Klasifikacija in analiza pokrajinskoekoloških dejavnikov}

V postopku izvedbe pokrajinskoekološko členitve smo upoštevali naslednje dejavnike:

- naklon,

- nadmorske višine,

- ekspozicije,

- geomorfološke oblike,

- geološka podlaga,

- prsti,

- povprečne letne temperature,

- povprečne letne količine padavin,

- gozdne združbe,

- raba tal.

Iz DMR25 smo v programu IDRISI 32 izdelali karte naklonov, višinskih pasov in ekspozicij. Nekateri sloji so bili že kategorizirani (temperature, padavine), pri večini pa smo sami opredelili funkcijske razrede (nakloni, višinski pasovi, ekspozicije) oziroma jih naknadno združevali v sorodne kategorije (raba tal, prsti, geološka podlaga, gozdne združbe). Pred sabo smo imeli cilj čim bolje prikazati značilnosti Zgornje Gorenjske. Pri določanju mej med razredi smo izhajali iz literature. $V$ večini primerov smo izdelali več različic in na osnovi njihove medsebojne primerjave izbrali tisto, ki je dala najboljše rezultate.

\subsection{Izbor dominantnih pokrajinskoekoloških dejavnikov}

Po natančni in časovno zamudni analizi vseh zbranih slojev GIS smo ugotovili, da je dominanten pokrajinski element relief oziroma natančneje: naklon površja, nadmorske višine in geomorfološke oblike. Ti dejavniki dajejo obravnavanemu študijskemu območju poseben pečat in so odločilno vplivali na njegov vsestranski razvoj ter na vlogo gozda. Imajo 
tudi visoko razločevalno vrednost, ki omogoča notranjo diferenciacijo študijskega območja in je zelo pomembna pri pokrajinskoekološkem kartiranju. Njegovi rezultati so namreč močno odvisni prav od pravilnega izbora dominantnih pokrajinskih elementov. Posebno pri raziskavah hribovitih in gorskih predelov tudi številni avtorji (npr. Zonneveld, 1989; Klijn in De Haes, 1994; Stritar 1990; Gams 1983, 1998; Natek v Špes in sod. 2002) navajajo relief kot dominanten ali vsaj kot enega izmed dominantnih dejavnikov, ki bistveno vpliva na vse druge pokrajinskoekološke prvine, vključno z gozdom.

\subsection{Določitev mejnih vrednosti dominantnih pokrajinskoekoloških dejavnikov}

V postopku pokrajinskoekološke členitve je bil ta korak najtežji. Pregledali smo veliko literature in ugotovili, da se mejne vrednosti v nekaterih primerih ujemajo, večkrat pa avtorji navajajo različne mejne vrednosti in jih tudi bolj ali manj argumentirano zagovarjajo. Iz tega razloga smo tako pri naklonu kot pri nadmorskih višinah pripravili večje število različic, ki smo jih primerjali med seboj in tudi z drugimi pokrajinskimi dejavniki, na osnovi česar smo se odločili za varianto, ki je dala najboljše rezultate.

\section{Naklon površja}

Pri določanju naklonskih razredov smo v presojo vzeli več klasifikacij in izdelali več kart z različnimi naklonskimi razredi. Klasifikacije so bile funkcijske, temeljile pa so predvsem na primernosti za različne človekove dejavnosti. V literaturi se, odvisno od namena in natančnosti klasifikacije ter strokovnega profila njenega avtorja, pojavljajo različne mejne vrednosti, ki pa so relativno enotne pri postavitvi prelomnih mej, kot je npr. meja primernosti za gradnjo in moderno kmetijstvo. Pri klasifikacijah je potrebna določena previdnost, saj nekateri avtorji naklon izražajo v stopinjah, drugi pa v procentih, med tema dvema enotama pa je bistvena razlika.

Pogačnik (1999) navaja, da so za gradnjo najprimernejša zemljišča do $5 \%\left(\cong 2,9^{\circ}\right)$, srednje primerna do $10 \%\left(\cong 5,7^{\circ}\right)$, medtem ko pomeni naklon nad $30 \%\left(\cong 17,2^{\circ}\right)$ oz. nad $20 \%\left(\cong 11,5^{\circ}\right)$ (odvisno od stabilnosti, geoloških in hidroloških razmer) omejitev za gradnjo.

Novak (v Stritar 1990) je izdelal tabelo, iz katere je razviden vpliv naklona zemljišč na možnost uporabe kmetijske mehanizacije. Po njegovih ugotovitvah se na območjih z nagibom do $10 \%$ lahko razvijejo skoraj vse kmetijske panoge in usmeritve in uporablja vsa mehanizacija, nagibi od 10 do $20 \%$ pa še dopuščajo uporabo težke mehanizacije in so primerni za poljedelstvo in živinorejo. Z naraščanjem naklona močno pada storilnost strojev. Na območjih z nagibom nad $65 \%\left(\cong 37,2^{\circ}\right)$ je možna le še uporaba motorne samohodne kosilnice pri pašno-košnem gospodarjenju planinskih kmetij (vendar je njena storilnost zmanjšana za več kot $40 \%$ ) in nekaterih strojev v vertikalnih, strmih vinogradih. Stritar (1990) na podlagi teh ugotovitev in tudi na podlagi uporabe tehnologije v gradbeništvu ugotavlja, da je od vseh najpomembnejša ločnica pri 20 \% nagiba, in dodaja, da se površine pod to mejo obravnavajo kot ravninske, vse druge pa kot gričevnate in hribovite. 
Podobne mejne vrednosti najdemo tudi v Navodilu o strokovnih merilih za določitev zemljišč v kategorije iz leta 1982. V I. kategoriji so zemljišča z naklonom od 0 do $10 \%$ (ugoden relief; uporaba vseh vrst mehanizacije, velika storilnost; prevlada njivskih površin), v II. od 10 do $20 \%$ (rahlo razgiban relief, blago valovit in gričevnat svet; uporaba večjih kmetijskih strojev otežena; prevlada njivskih površin slabše kvalitete), v III. od 20 do 45 \% (razgiban relief; otežena možnost kmetijske rabe tal; prepletanje njiv in travnikov), v V. kategoriji zemljišča z naklonom, večjim od 45 \% (strm relief, strojna obdelava zelo omejena; prevlada travnikov. Pri VI. in VII. kategoriji naklon ni opredeljen, v VI. spadajo zemljišča na hribovitih in gorskih območjih, kjer uporaba kmetijske mehanizacije ni mogoča, v VII. pa zemljišča, kjer zaradi naravnih danosti (npr. neobrasel planinski svet, skalnat svet) kmetijska raba tal ni mogoča. V novi Uredbi o kriterijih za določitev območij z omejenimi možnostmi za kmetijsko dejavnost iz leta 2003 so za hribovita oziroma gorska območja opredeljene vse površine, katerih povprečni nagib je najmanj 20 \% in površine s povprečnim nagibom najmanj $15 \%$, če je hkrat njihova povprečna nadmorska višina najmanj 500 metrov.

Natek (v Špes in sod. 2002) ugotavlja, da je naklon najpomembnejši omejitveni dejavnik za človeka v prostoru in pri naklonskih razredih navaja možnosti oz. omejitve za človekovo delovanje. Leta 1983 naklon razdeli v sedem razredov, pri katerih so zlasti pomembne naslednje meje (Natek 1983):

- $6^{\circ}-\mathrm{v}$ kmetijstvu možna uporaba vse mehanizacije, ugodno za gradnjo naselij in komunikacij,

- $12^{\circ}-\mathrm{v}$ kmetijstvu se ne morejo uporabljati težki stroji, poljedelstvo možno le s konturnim oranjem, otežena gradnja naselij in komunikacij, zgornja meja za gradnjo mest,

- $20^{\circ}$ - v kmetijstvu obdelovanje le ročno ali s posebnimi traktorji, zgornja meja za njive, omejena gradnja hiš in komunikacij.

Leta 2002 (v Špes in sod.) klasifikacijo za malenkost spremeni in skrči na štiri razrede:

- $0-5^{\circ}-$ ni omejitve rabe,

- 5-12 - moderna kmetijstvo in poselitev možna z manjšimi omejitvami,

- $12-20^{\circ}$ - zgornja meja modernega kmetijstva in poselitve,

- $\operatorname{nad} 20^{\circ}$ - obdelava in poselitev zelo omejena.

Zaradi teme naloge je bil za nas posebej pomemben vpliv naklona na gozdne funkcije oziroma meje za opredelitev varovalne funkcije gozda. Pravilnik o gozdnogospodarskih in gozdnogojitvenih načrtih (1998) določa, da imajo prvo stopnjo varovalne funkcije gozda (ki določa način gospodarjenja z gozdom) vsi gozdovi na kompaktni matični podlagi z naklonom nad $35^{\circ}$ in gozdovi na erodibilni ali plazljivi matični podlagi z naklonom nad $25^{\circ}$, drugo stopnjo (ki pomembno vpliva na način gospodarjenja z gozdom) pa gozdovi na erodibilni ali plazljivi matični podlagi z naklonom od 15 do $25^{\circ}$. Z vidika gospodarjenja z gozdom je tako posebej pomembna ločnica pri $35^{\circ}$ naklona, nad katero imajo vse gozdne površine varovalno funkcijo prve stopnje.

$\mathrm{Na}$ osnovi pregledane literature in preizkusov več variant $\mathrm{z}$ različnimi naklonskimi razredi smo ugotovili, da nam najboljše rezultate prinese klasifikacija v pet razredov. Pri določanju mej med razredi smo najbolj upoštevali Natkovo klasifikacijo (v Špes in sod., 
2002), ki pomeni nekakšno sintezo ugotovitev različnih strok o vplivu naklonov na človekovo dejavnost. Pri določitvi meje med četrim in petim razredom pa smo izhajali iz ugotovitev gozdarske stroke, ki je vrednost $35^{\circ}$ določila za mejo, nad katero imajo vsi gozdovi varovalno funkcijo prve stopnje.

Naklonski razredi, ki smo jih uporabili v postopku pokrajinskoekološke členitve:

- $\quad 0-5,9^{\circ}$ (ni omejitev rabe, v kmetijsvu možna uporaba vse mehanizacije),

- 6-11, $9^{\circ}$ (moderno kmetijstvo in poselitev možna z manjšimi omejitvami),

- $12-19,9^{\circ}$ (zgornja meja modernega kmetijstva in poselitve),

- 20-34, $9^{\circ}$ (pri Natku $32^{\circ}$ : njive in gradnja hiš izjemoma, komunikacije ogrožene zaradi usadov, plazov, raba tal: travniki, pašniki in predvsem gozd)

- $35^{\circ}$ in več (prva stopnja varovalne funkcije gozda, pri Natku več ko $32^{\circ}$ : možni pašniki, ki pa so ogroženi zaradi erozije).

Na tako strukturirani karti naklonov (slika 1) se je kot najbolj izrazita izkazala ločnica $20^{\circ}$ naklona kot zgornja meja modernega kmetijstva in poselitve. Na karti, kjer smo prikazali površine z naklonom do $20^{\circ}$, so zelo jasno izstopale vse doline in planote, tako da smo to mejo vzeli kot glavno ločnico pri pokrajinskoekološki členitvi.

\section{Slika 1: Nakloni površja na Zgornjem Gorenjskem}

Figure 1: Surface slopes in the Upper Gorrenjska region

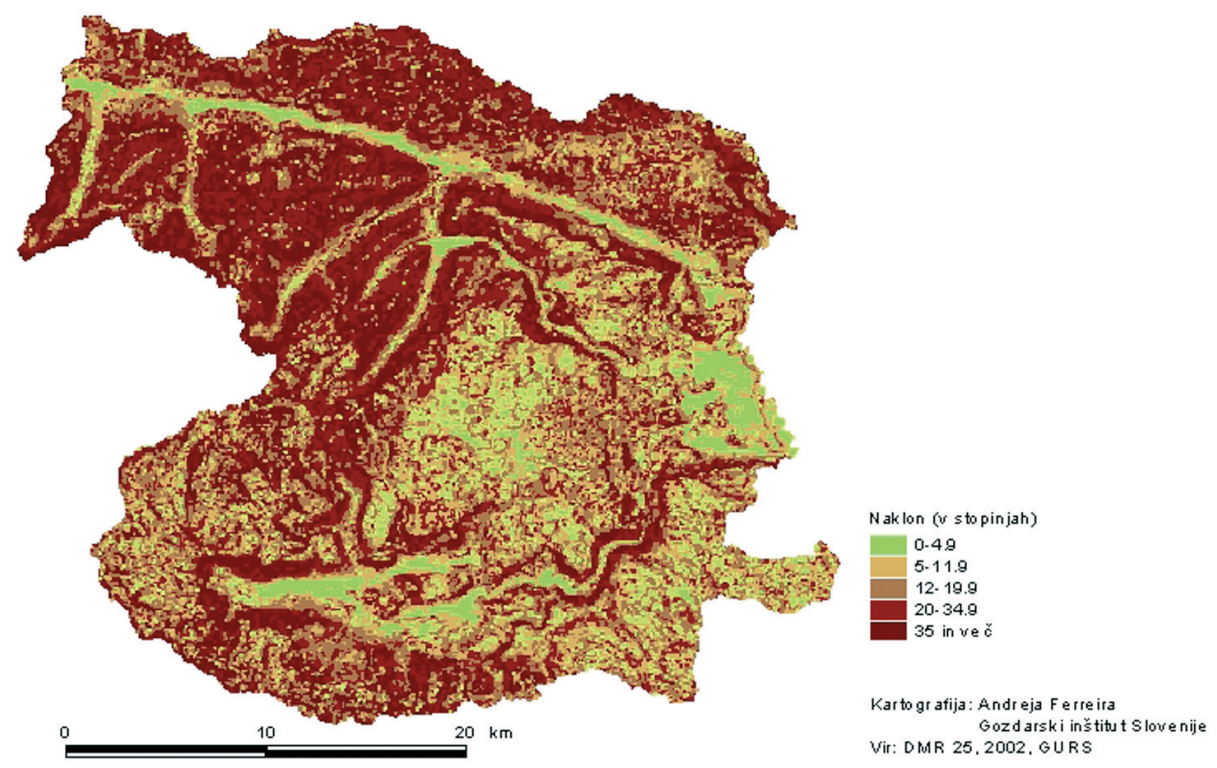

Tudi meje med preostalimi razredi prinašajo koristne informacije. Na karti naklonov do $5^{\circ}$ so lepo vidna večja strnjena območja ravnega sveta v Blejskem kotu, Bohinju, dolinah obeh 
Sav, Radovni, Krmi in Planici. Če k tem dodamo še površine z naklonom od 5 do 11, $9^{\circ}$, pridejo do izraza še vse preostale doline (Voje, Kot, Vrata, Pišnica), izstopajo pa tudi najizrazitejše uravnave, predvsem Pokljuka in Jelovica ter deloma Mežakla. Naklon $12^{\circ}$ pomeni mejo med ravnimi in položnimi območji, kjer je teoretično možno moderno kmetijstvo in poselitev le z manjšimi omejitvami in strmimi območji različnih razponov, kjer so sodobne človekove dejavnosti močno omejene ali celo neizvedljive. Če naklon $12^{\circ}$ pretvorimo v odstotke, dobimo 21,3 \%, kar je blizu vrednosti 20 \%, ki jo je (kot smo že omenili) Stritar (1990) opredelil kot bistveno ločnico v prostoru. Zaradi visokih nadmorskih višin pa sta $\mathrm{v}$ našem primeru tudi na večjem delu območij z naklonom do $12^{\circ}$ kmetijstvo in poselitev močno omejena.

$\mathrm{Na}$ večini preostalih območij se nakloni gibljejo v razponu od 20 do $35^{\circ}$, razen na severnih pobočjih in v osrednjem delu Julijskih Alp, kjer prevladujejo nakloni nad $35^{\circ}$. V primeru, da so ta območja porasla z gozdom, opravlja ta varovalno funkcijo prve stopnje.

\section{Nadmorske višine}

Na osnovi literature sta se nam pri nadmorskih višinah kot posebej pomembni izkazali dve ločnici. Prva je 600 metrov nad morjem, ki jo je Stritar (1990) skupaj z nagibom 20 \% uporabil pri delitvi Slovenije na štiri naravne regije. Podobno Marinček (1987) pri 600 metrih potegne mejo med podgorskim (submontanskim) in gorskim (montanskim) rastlinskim pasom, čeprav dodaja, da se na prisojnih legah podgorski pas lahko razteza celo do 700 metrov visoko, na hladnih osojnih pa le do 400 ali 450 metrov. Tudi v Navodilu o strokovnih merilih za določitev zemljišč v kategorije iz leta 1982 se je meja 600 metrov nadmorske višine upoštevala kot ločnica v naravnih razmerah in naj bi se kot taka odražala tudi v rabi zemljišč. V Uredbi o kriterijih za določitev območij z omejenimi možnostmi za kmetijsko dejavnost iz leta 2003 so se za hribovita oziroma gorska območja opredelile vse površine, ki ležijo na nadmorski višini 700 metrov ali več, in tudi vsa zemljišča, ki ležijo na nadmorski višini najmanj 500 metrov, če je njihov naklon najmanj 15 \%. Ostre meje med nižinskimi in gričevnatimi ter hribovitimi oziroma gorskimi območji ni mogoče potegniti, na podlagi dosedanjih dognanj pa se giblje okrog 600 metrov nad morjem.

Druga ločnica je zgornja gozdna meja, ki smo jo na osnovi literature določili na 1800 metrih nadmorske višine. Tudi tukaj ne gre za ostro mejo, saj se v Sloveniji zgornja gozdna meja pojavlja na zelo različnih višinah. Gams (1960) ugotavlja, da je gozdna meja na Pokljuki na 1700 metrih, v Karavankah med 1800 in 1900 metri, v Kamniških Alpah med 1700 in 1800 metri, na Snežniku med 1500 in 1550 metri in na Goljakih na 1440 metrih. Tudi za Julijske Alpe Šolar (1998) navaja, da je gozdna meja neenotna in na južni strani ne presega 1600 metrov nadmorske višine, v notranjosti pa je na višini 1800 metrov, tvorita pa jo smreka in macesen. Počkar in Stritih (1987) ugotavljata, da na nekaterih reliefno primernih krajih macesnov gozd uspeva celo do višine 1900 metrov in da gozdno mejo večinoma določajo orografski dejavniki. Na ožjem študijskem območju na Pokljuki je bilo s fotointerpretacijo aeroposnetkov ugotovljeno, da gozdna meja v povprečju poteka na 1750 metrih nadmorske višine (Ferreira in sod. 2000). Marinček (1987) locira subalpinski pas na nadmorske višine med 1450 oz. 1500 in 1800 metri, kjer naj bi potekala tudi zgornja meja potencialne naravne vegetacije, ki jo tvorijo bukovi gozdovi. 
S proučevanjem zgornje gozdne meje $\mathrm{v}$ Julijskih Alpah se je podrobno ukvarjal Lovrenčak (1987), ki ugotavlja, da jo gradita macesen in smreka, ki rasteta tudi na drevesni meji. Macesna je več v osrednjem delu gorovja, smreke pa v južnih robnih delih Julijcev. Potek gozdne meje je zaradi razgibanega reliefa zelo neenakomeren in vijugast. V južnih in vzhodnih pogorjih, kjer je relief manj razčlenjen in v višjih legah bolj planotast (Komna, Fužinarska planota, Pokljuka), je v pasu od 1600 do 1800 metrov. Na pobočjih nad Dolino Triglavskih jezer se gozdna meja končuje zelo neenakomerno, na nadmorskih višinah od 1700 do 1880 metrov. Dokaj visoko sega v visokem srednjem delu gorovja med Debelim vrhom, Jezerskim Stogom, Toscem in Triglavom, kjer macesnovo-smrekov gozd porašča pobočja do okoli 1800 metrov. V zelo razčlenjenem severnem delu Julijskih Alp z globokimi dolinami in strmimi pobočji je gozdna meja nizka in se giblje večinoma med 1200 in 1500 metri. Lovrenčak (1987) poudarja, da je v Julijskih Alpah treba ločevati naravno (primarno) in antropogeno (sekundarno) gozdno mejo. Med naravnimi dejavniki sta glavna podnebje in relief, zato ločujemo klimatsko (termično, vetrno) ter orografsko gozdno mejo. Klimatsko (termično) mejo gozd težko doseže zaradi reliefa in delovanja človeka. Vetrna meja je dejanska meja gozda na grebenih, vrhovih, pobočjih pod sedli - povsod tam, kjer pihajo stalni in močni vetrovi (npr. na severni strani Spodnjih Bohinjskih gora). Orografska meja je prisotna zlasti na pobočjih dolin Vrat, Kota in Krme, na severni strani Kaninskega pogorja in v osrednjem delu gorovja. Klimatska (termična) gozdna meja (ki je zaradi orografije in vpliva človeka abstraktna) se v Julijskih Alpah giblje od 1600 metrov na Stolovem pogorju in na južnih pobočjih Spodnjih Bohinjskih gora do 1900 metrov v osrednjem delu Julijskih Alp in na njihovem severnem robu.

Na osnovi naštetih virov smo se odločili, da bomo za enotno ločnico določili višino 1800 metrov. To smo primerjali z mejo gozda na karti rabe tal (2002) in ugotovili, da se v veliki meri ujemata, zato se je naša odločitev izkazala kot pravilna. Pri nadaljnji razporeditvi nadmorskih višin v razrede smo se odločali med 200- in 300-metrskimi pasovi. Izdelali smo obe varianti ter ju primerjali z drugimi dejavniki, predvsem z naklonom, na osnovi česar smo se odločili za 300-metrske pasove (slika 2). Poleg pasu nad zgornjo gozdno mejo (> $1800 \mathrm{~m}$ ) so prišle lepo do izraza predvsem doline. V pasu od 300 do 600 metrov so izstopali Bohinj, dolina Save Bohinjke, Blejski kot in spodnji del Zgornjesavske doline, čeprav je treba poudariti, da višin pod 400 metrov na študijskem območju sploh ni (najnižja nadmorska višina je 411 metrov na območju Blejskega kota). Na nadmorskih višinah od 600 do 900 metrov ležijo preostali del Zgornjesavske doline in stranske alpske doline delno (Krma, Kot, Vrata, Pišnica) ali v celoti (Radovna, Voje). Ves preostali del stranskih alpskih dolin je v pasu od 900 do 1200 metrov, dolina Planice pa skoraj v celoti leži v tem pasu.

Druge geomorfološke enote iz karte višinskih pasov niso bile jasno razvidne, čeprav se je na osnovi večjih strnjenih območij z bolj ali manj enotnimi nadmorskimi višinami dalo razbrati kje so uravnave (najbolj izrazito v primeru Pokljuke).

\section{Geomorfološke oblike}

Kot tretji dejavnik smo pri pokrajinskoekološki členitvi upoštevali glavne geomorfološke oblike, in sicer:

- doline, 
- pobočja,

- planote.

Geomorfološka izoblikovanost površja je bila posebno pomembna pri oblikovanju dokončnih meja pokrajinskoekoloških enot, saj smo jih izrisali na topografskih kartah $\mathrm{v}$ merilu $1: 25.000$.

Slika 2: Višinski pasovi na Zgornjem Gorenjskem

Figure 2: Altitude zones in the Upper Gorrenjska region

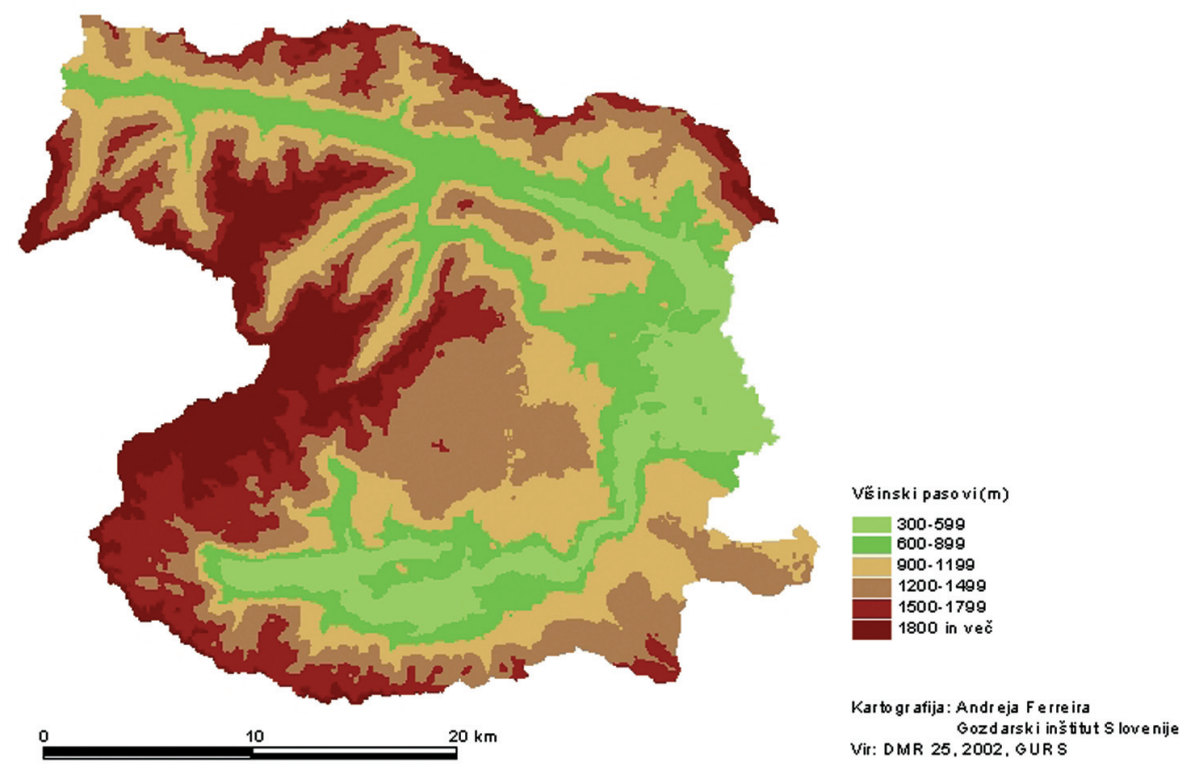

\section{REZULTAT POKRAJINSKOEKOLOŠKE ČLENITVE}

Pokrajinskoekološka členitev je dvostopenjska. V prvem koraku smo izvedli tipizacijo, to je členitev pokrajine v manjše pokrajinske enote po načelu podobnosti. V drugem koraku smo uporabili regionalizacijo in pokrajinsko ekološke tipe nadalje členili po načelu posamičnosti in posebnosti. Rezultat je 5 pokrajinskoekoloških tipov in 19 pokrajinskoekoloških enot. Pokrajinskoekološki tipi so označeni z rimskimi, pokrajinskoekološke enote pa z arabskimi številkami. Pokrajinskoekološki tipi so prikazani na sliki 3, pokrajinskoekološke enote pa na sliki 4.

\section{Pokrajinskoekološki tipi in enote:}

I. Glavne alpske doline (prevladujoča n. v. do 600 oz. $900 *$ m, naklon $<20^{\circ}$ ) 
Slika 3: Pokrajinskoekološki tipi na Zgornjem Gorenjskem

Figure 3: Landscape-ecological types in the Upper Gorenjska region

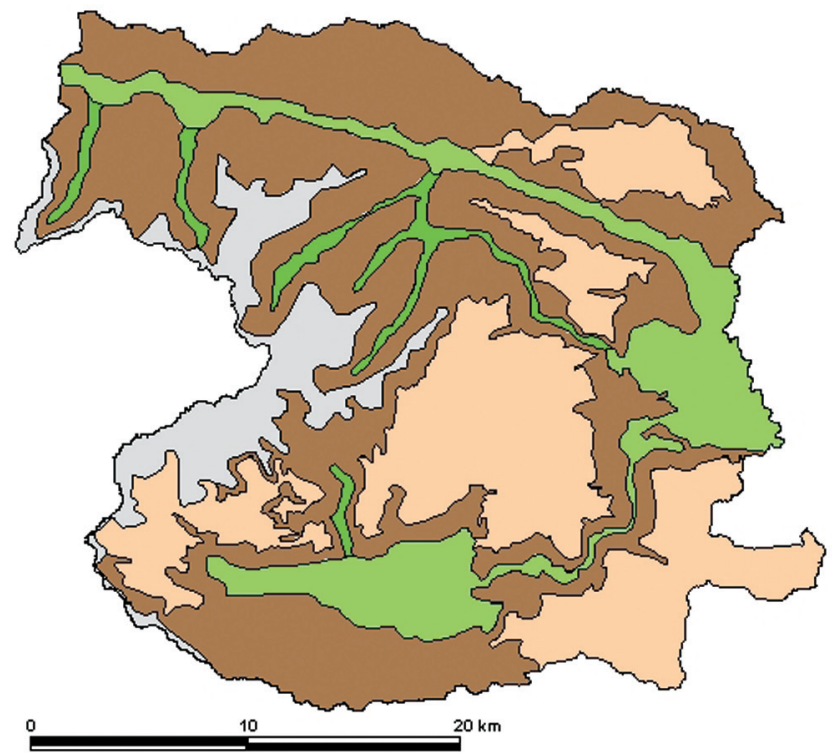

glaune alpske doline

str anske alpske doline

plan ote

strma pobočja nad dolina mi

suet $n$ ad zgornjo gozd no mejo

Autorica karte: Andreja Ferreira

Gozd arski inštitut Slovenije

Slika 4: Pokrajinskoekološke enote na Zgornjem Gorenjskem

Figure 4: Landscape-ecological units in the Upper Gorenjska region
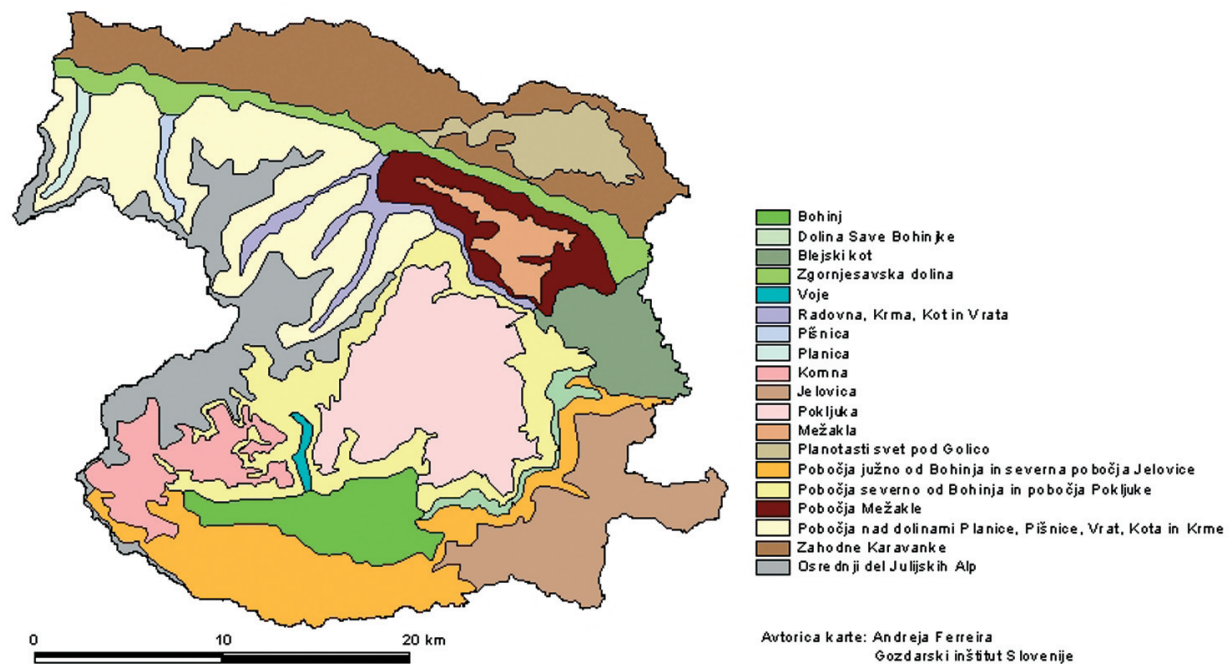
1. Bohinj

2. Dolina Save Bohinjke

3. Blejski kot

4. Zgornjesavska dolina*

II. Stranske alpske doline (prevladujoča n. v. 600-1200 m, naklon $<20^{\circ}$ )

1. Voje

2. Radovna, Krma, Kot in Vrata

3. Pišnica

4. Planica

III. Planote (prevladujoča n. v. 900-1800 m, naklon $<20^{\circ}$ )

1. Komna

2. Jelovica

3. Pokljuka

4. Mežakla

5. Planotasti svet pod Golico

IV. Strma pobočja nad dolinami (n. v. 600-1800 m, naklon $>20^{\circ}$ )

1. Pobočja Spodnjih Bohinjskih gora in severna pobočja Jelovice

2. Pobočja severno od Bohinja ter pobočja Pokljuke

3. Pobočja Mežakle

4. Pobočja nad dolinami Krme, Kota, Vrat, Pišnice in Planice

5. Zahodne Karavanke

V. svet nad zgornjo gozdno mejo (n. v. >1800)

Osrednji del Julijskih Alp

\section{SKLEP}

Členitev Zgornje Gorenjske na 5 pokrajinskoekoloških tipov in 19 pokrajinskoekoloških enot je pokazala veliko notranjo diferenciacijo območja, ki v primeru obstoječih teritorialnih enot, kot so katastrske občine, občine itd. ne pridejo do izraza. Meje teh ne potekajo po naravnih enotah, zato so znotraj njih zelo raznolike pokrajinskoekološke razmere, ki pa se v povprečnih vrednostih na ravni teritorialnih enot zabrišejo. Pri pokrajinskoekološkem metodološkem pristopu se, nasprotno, poudari ravno specifičnost posameznih pokrajinskoekoloških enot, pokaže pa se tudi zelo močan vpliv pokrajinskoekoloških dejavnikov na delovanje človeka. Homogenost pokrajinskoekoloških tipov in enot omogoča, v nasprotju s heterogenostjo teritorialnih enot (upravne enote, občine, katastrske občine ...), preprostejšo interpretacijo podatkov in boljše rezultate. Edina večja pomanjkljivost omenjenega pristopa je, da obstoječa statistična podatkovna baza ni prirejena takšni prostorski ravni obravnave, pomanjkanje ustreznih podatkov pa vodi $\mathrm{v}$ nekatera posploševanja, ki $\mathrm{v}$ nasprotju $\mathrm{s}$ predhodnimi ugotovitvami zmanjšujejo zanesljivost rezultatov. 


\section{Viri in literatura}

Cilji kakovosti okolja za Alpe. 2000. Zaključno poročilo delovne skupine za specifične cilje kakovosti okolja v gorah pri Alpski konvenciji. Hain, Zvezni urad za okolje.

DMR 25. 2002. Geodetska uprava Republike Slovenije. Ljubljana.

Ferreira, A., Kušar, G., Hočevar, M. 2000. Kartiranje zgornje gozdne meje v Triglavskem narodnem parku z uporabo metod digitalne fotogrametrije. Geografski informacijski sistemi v Sloveniji 1999-2000. Ljubljana.

Gams, I 1960. O višinski meji naseljenosti, ozimine, gozda in snega v slovenskih gorah. Geografski vestnik 32. Ljubljana.

Gams, I., 1983. Geografske značilnosti Slovenije. Ljubljana.

Gams, I., 1986. Osnove pokrajinske ekologije. Ljubljana.

Gams, I. 1998. Pokrajinsko ekološka sestava Slovenije. Geografija Slovenije. Ljubljana.

Karta povprečnih letnih temperatur, izdelana na podlagi DMR 100, zanesljivost vrednosti 1km, obdobje 1961-1990. Hidrometeorološki zavod Slovenije. Ljubljana.

Karta povprečnih letnih količin padavin, izdelana na podlagi DMR 100, zanesljivost vrednosti 1km, obdobje 1961-1990. Hidrometeorološki zavod Slovenije. Ljubljana.

Karta gozdnih združ 1:100.000, datum vira: 1970, datum zajema 2003. Biro za gozdarsko načrtovanje. Ljubljana.

Karta rabe kmetijskih zemljišč 1:25.000. 2002. Ministrstvo za kmetijstvo, gozdarstvo in prehrano. Ljubljana.

Klijn, F., De Haes, H., A., U. 1994. A hierarchical approach to ecosystems and its implications for ecological land classification. Landscape Ecology 2. Hague.

Leser, H. 1976. Landschaftsökologie. Stuttgart.

Lovrenčak, F. 1987. Zgornja gozdna meja v Julijskih Alpah in visokih kraških planotah Slovenije. Geografski zbornik 26. Ljubljana.

Marinček, L. 1987. Bukovi gozdovi na Slovenskem. Ljubljana.

Natek, K. 1983. Metoda izdelave in uporabnost splošne geomorfološke karte. Magistrska naloga. Filozofska fakulteta, Oddelek za geografijo. Ljubljana.

Natek, K. 1998. O regionalizaciji Slovenije. Geografski vestnik 70. Ljubljana.

Navodilo o strokovnih merilih za določitev zemljišč v kategorije. Uradni list SRS št.45/82.

Osnovna geološka karta. Datum vira: 1967-1998, datum zajema: 1998-2003. Geološki zavod Slovenije. Ljubljana.

Pedološka karta 1: 25.000, 1999. BF, Oddelek za agronomijo, Center za pedologijo in varstvo okolja. Ljubljana.

Plut, D. 1999. Regionalizacija Slovenije po sonaravnih kriterijih. Geografski vestnik 71. Ljubljana.

Počkar, B., Stritih, J. 1987. Strategija rasti gozda na zgornji gozdni meji - primerjava med Dinaridi in Julijskimi Alpami.Diplomska naloga. Biotehniška fakulteta, VTOZD za gozdarstvo. Ljubljana.

Pogačnik, A. 1999. Urbanistično planiranje. Univerza v Ljubljani, Fakulteta za gradbeništvo in geodezijo. Ljubljana.

Praper, S. 1997. Trajnostni prostorski in regionalni razvoj ter regionalizacija Slovenije. IB Revija 12. Ljubljana. 
Pravilnik o gozdnogospodarskih in gozdnogojitvenih načrtih. Uradni list RS, št. 5/98.

Stritar, A. 1990. Krajina, krajinski sistemi - Raba in varstvo tal v Sloveniji. Ljubljana.

Šolar, M. 1998. Upravljanje z gozdom in vloga gozda v zavarovanem območju Triglavskega narodnega parka - gozdarski in naravovarstveni interesi. Gorski gozd, Zbornik referatov.BF, Oddelek za gozdarstvo in obnovljive gozdne vire. Ljubljana.

Špes in sod. 2002. Študija ranljivosti okolja. Ljubljana.

TTK 1:25.000 in $1: 50.000$. 1994. Geodetska uprava Republike Slovenije. Ljubljana.

Uredba o kriterijih za določitev območij z omejenimi možnostmi za kmetijsko dejavnost.Uradni list. RS, št.18/03.

Wollesen, D. 1997. Lanschaftsökologische vergleichsstudie zur nordeuropäischen tundra (NW-Spitzbergen/N-Schweden).Giessener geograpische schriften, Heft 74, Selbstverlag des Geographischen Institutes der Justus-Liebig-Universität. Giesen.

Zonneveld, I., S. 1989: The land unit - a fundamental concept in landscape ecology and its applications. Landscape ecology 2 . Hague.

\section{LANDSCAPE-ECOLOGICAL DIVISION OF THE UPPER GORENJSKA REGION}

\section{Summary}

In the study of the relationship between the individual landscape-forming elements and their influence on the use of landscape and human activity, the landscape-ecological methods proved to be most appropriate. What is typical of these methods is their emphasis on a holistic assessment of landscape-ecological elements and their interrelations. Because landscape ecology does not have a uniform and pre-determined method, every new research entails an adaptation of the method, which at the same time requires an adaptation of the accuracy of the collected data and of the spatial level where the research is being conducted respectively.

In our case, we developed the division of the landscape-ecological units as a basis for the analysis of the permanence of the development of Upper Gorenjska up to the present, the existing forest functions and the course of the future development, with emphasis on the role of the forest. In its execution, we attributed special significance to the forest and the factors that have a crucial influence on its layout and its functions. The area of our study was Upper Gorenjska which combines four municipalities: Bohinj, Bled, Jesenice and Kranjska Gora.

We attained the landscape-ecological division with the help of a geographical information system. We analyzed the following landscape-ecological factors: slope, altitude, expositions, geo-morphological shapes, geological substratum, soils, average yearly temperatures, forest associations, and ground use. After a precise and time-consuming analysis of all the collected GIS strata, we established that the prevailing landscape element is the relief, or to be more precise, the slope of the surface, the altitudes and the geo-morphological shapes. These factors have a special importance in the area of our study and have had a crucial influence on its general development and the role of the forest. They also have a high distinguishing value, which facilitates the inner differentiation of the study area and is at the same time very 
important for landscape-ecological charting. We determined the border values of the principal landscape-ecological factors on basis of literature and reciprocal comparisons of the attained variants.

The landscape-ecological division comprised of two steps. In the first step we carried out a typification, that is, a division of the landscape into smaller landscape units according to the principle of similarity. In the second step we used regionalism and further divided the landscape-ecological types according to the principle of individuality and particularity. The results are 5 landscape-ecological types and 19 landscape-ecological units. The landscapeecological division demonstrated an extensive inner differentiation of the area, which was not very pronounced in the case of the existing territorial units like cadastral districts, municipalities etc. The homogeneity of landscape-ecological types and landscape-ecological units permits a simpler interpretation of the data obtained and better results. A disadvantage of the mentioned approach, however, is that the existing statistical database is not adapted to an examination at the spatial level, which leads to certain generalizations that, in contrast to previous findings, lessen the reliability of the results. 